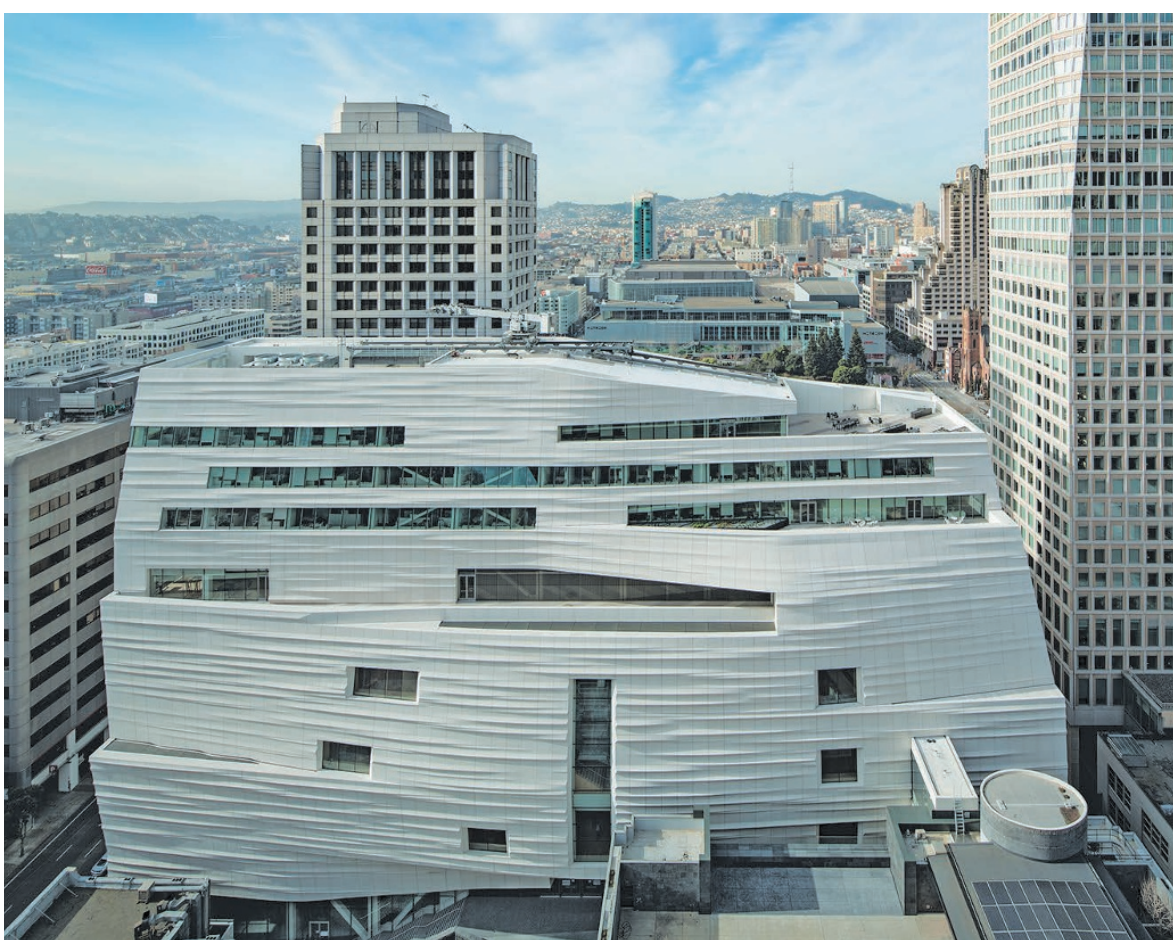

The San Francisco Museum of Modern Art's extension more than doubles its exhibition space.

\title{
ARTS
}

\section{California on camera}

\section{John Gilbey lauds San Francisco’s vastly expanded showcase for modern art and photography.}

\section{A} mid-twentieth-century sciencefiction writer's image of the City of the Future: that is how the approach to the San Francisco Museum of Modern Art (SFMOMA) in California can seem. On a clear spring afternoon, the black and white stone oculus of the Mario Bottadesigned building emerges from the foothills of the Financial District like the prow of a grounded starship. Now, a new addition more than doubles SFMOMA's exhibition space. The expansion has allowed SFMOMA to remodel public spaces, conservation resources and study areas for a new generation of researchers and visitors.

SFMOMA has had a strong track record in covering the diversity of Bay Area technological innovation and artistic richness. The exhibition 010101: Art in Technological Times, launched in 2001, featured sound installations by musician Brian Eno, as well as video and live digital landscapes - ephemeral work that also brought curatorial challenges. In 2014, the museum showcased geek power at its Art + Data Day, a hackathon that challenged collaborative teams to interrogate the museum collection metadata. Now, with the expansion, SFMOMA boasts the
Reopening

San Francisco Museum of Modern Art, California. 14 May.

California and the West

San Francisco Museum of Modern Art, California. 14 May - 5 September.

Pritzker Center for Photography, which offers 1,400 square metres to display the museum's renowned photography holdings, including iconic works by nineteenth- and twentiethcentury greats such as Carleton Watkins and Ansel Adams. It is now the largest US gallery space dedicated to the technology.

White and multifaceted, the wing's rippled fibreglass-reinforced polymer cladding - designed to echo the Bay Area's famous fogs - has a dynamic look in the changing light. The transdisciplinary approach of its innovative architects Snøhetta integrates architectural, landscape and interior design; their portfolio includes the Bibliotheca Alexandrina in Alexandria, Egypt. The edifice has been costly both financially - at US $\$ 305$ million - and practically, because the museum building has been closed since June 2013. Until recently, red hoardings enjoined unlucky visitors to "Think Outside the Building" - a reference to its successful touring outreach programme, SFMOMA On The Go.

Inside, the ample room for photography displays gives the museum's 17,000-piece collection real breathing space. SFMOMA has been amassing the holdings, which range from early Daguerreotypes to cuttingedge digital images, since it opened in 1935. This permanent collection is categorized by themes that speak to the unique geographic and cultural position of the city. The local heroes of the Group f/64 collective - Adams, Edward Weston, Imogen Cunningham - are inevitably strongly represented. But the collection of Japanese photography, perhaps the finest outside Japan, demonstrates how San Francisco considers itself to be a Pacific community. Modernist and Surrealist photographers such as Alfred Stieglitz and Man Ray also feature.

Senior curator of photography Sandra Phillips talked to me about the technology's special place in San Francisco - blessed with a photogenic mix of topography, microclimate and infrastructure - and in California, a state endowed with rare geological and ecological richness. Pioneering regional photographers such as Watkins and Adams created a legacy of iconic monochromes. The expansion, Phillips told me, allows for more study as well as display of this deep resource: the Photography Interpretive Center, for instance, enables visitors to explore the lives and work of photographers through video interviews and films.

Phillips is curator of California and the West, an exhibition that traces the portrayal of Californian wilderness and land development in photographs over time. The show, she notes, "will reveal the evolution in our understanding of land use, first as development in mining and logging, then as protection". Along with the work of Robert Adams, who as part of the 1970s New Topographics movement revealed the regional realities of urban encroachment, there will be images by early masters - Dorothea Lange, Minor White and Group f/64. A more contemporary lens on the landscape is provided by Richard Misrach, Larry Sultan, Michael Light and Trevor Paglen.

The expansion offers SFMOMA a way to redefine the role of a modern art museum in a city poised between a vast, sometimes invasive, high-tech culture and an older, perhaps simpler, tradition in a technological medium. And by presenting itself as a public, eclectic resource offering free entry in perpetuity to under-18s, it is setting off beneficial ripples in local culture. Today's young visitors are the digital natives who will shape the future of both technology and the arts.

John Gilbey is a science and science-fiction writer and photographer. Twitter:@John_Gilbey 